\title{
INTEGRASI ANALITICAL HIERARCHY PROCESS-FUZZY DALAM PEMILIHAN SUPPLIER
}

\author{
Dolly Rommer ${ }^{1^{*}}$, Daniel B. Paillin ${ }^{2}$, dan Johan M Tupan ${ }^{3}$ \\ ${ }^{1}$ Jurusan Teknik Industri Fakultas Teknik Universitas Pattimura, Ambon, 97233 \\ *Email: dollymeyke@gmail.com \\ 2Jurusan Teknik Industri Fakultas Teknik Universitas Pattimura, Ambon, 97233 \\ Email: dani.ti.fatek@gmail.com \\ 3Jurusan Teknik Industri Fakultas Teknik Universitas Pattimura, Ambon, 97233 \\ Email: johan.tupan@fatek.unpatti.ac.id
}

\begin{abstract}
Abstrak. Penelitian ini membahas tentang pemilihan supplier bahan baku kayu dengan menggunakan metode AHP-F. Masalah yang dihadapi UD. Bless Mebel adalah sulitnya menentukan supplier mana yang memiliki performasi yang baik dari segi harga, kualitas, pelayanan, pengiriman, ketetapan jumlah, lokasi serta jaminan dan klaim. Dengan banyaknya pesaing dan harga bahan baku berbeda-beda dari setiap supplier. Banyak ditemukan kecacatan bahan baku seperti retakan kayu, kayu berlubang dan pecah di bagian ujung kayu, warna kayu, panjang dan bentuk kayu. Rencana pengiriman yang terkadang banyak dikeluhkan oleh perusahaan yang mana pengiriman tidak sesuai dengan jadwal dalam perjanjian. Hasil pengolahan data yang dilakukan dengan metode AHP fuzzy menunjukan kriteria yang menjadi prioritas dalam pemilihan supplier adalah kriteria harga yang memiliki besar bobot 0,47. Dengan memperhatikan ketujuh bobot kriteria yang telah diperoleh supplier yang direkomendasikan untuk diprioritaskan adalah supplier terbaik berdasarkan bobot prioritas tertinggi yaitu supplier $\mathrm{C}$ dengan bobot 0,39 kemudian supplier A dengan bobot 0,37 dan yang ketiga adalah supplier B dengan bobot 0,24.
\end{abstract}

Kata kunci: Pemilihan Supplier, Analytic Hierarchy Process, Fuzzy

\begin{abstract}
This study discusses the selection of wood raw material suppliers using the AHPF method. Problems by UD. Bless Furniture is the difficulty of determining which supplier has good performance in terms of price, quality, service, delivery, quantity determination, location as well as guarantees and claims. With many competitors and different raw material prices from each supplier. Many raw materials such as wood cracks are hollow and broken at the ends of the wood, the color of the wood, and the shape of the wood. Delivery plans that are often complained by companies where delivery is not according to the schedule in the agreement. The results of data processing carried out by the AHP fuzzy method show that the criteria that become a priority in supplier selection are the price criteria which have a weight of 0.47. By taking into account the seven criteria above, it is obtained that the supplier recommended being prioritized as the best supplier based on the highest priority weight, namely supplier $C$ with a weight of 0,39 then supplier A with a weight of 0,37 and the third is supplier B with a weight of 0,24.
\end{abstract}

Keywords : Supplier selection, Analytic Hierarchy Process, Fuzzy

\section{PENDAHULUAN}

Pemilihan Supplier merupakan salah satu hal penting dalam aktivitas pembelian dan pembelian merupakan aktivitas penting bagi perusahaan. [1] Pembelian bahan baku, dan persediaan merepresentasikan porsi yang cukup besar pada produk jadi.
UD. Bless Mebel merupakan salah satu usaha dagang yang berlokasi di Kota Masohi. Perusahaan ini merupakan perusahaan yang bergerak dalam industri furniture dengan sistem produksi berupa make to order yang mempunyai beberapa Supplier sebagai pemasok bahan baku kayu. 
Pemilihan Supplier yang baik akan melancarkan seluruh proses produksi perusahaan, menghasilkan produk jadi yang berkualitas dan menghasilkan keuntungan bagi perusahaan. Bahan baku yang kayu yang akan digunakan UD. Bless Mebel diperoleh dari beberapa Supplier yaitu Somel Ari, owner kayu di daerah Sepa dan Owner kayu didaerah Tambilow. Dalam penelitian kali ini akan ditentukan Supplier terbaik yang akan diusulkan kepada UD. Bless Mebel dengan pertimbangan yang sudah dipilih.

Masalah yang dihadapi UD. Bless Mebel adalah sulitnya menentukan supplier mana yang memiliki performasi yang baik dari segi harga, kualitas, pelayanan, pengiriman, ketetapan jumlah, lokasi serta jaminan dan klaim. Dengan banyaknya pesaing dan harga bahan baku berbeda-beda dari setiap supplier. Banyak ditemukan kecacatan bahan baku seperti retakan kayu, kayu berlubang dan pecah di bagian ujung kayu, warna kayu, panjang dan bentuk kayu. Rencana pengiriman yang terkadang banyak dikeluhkan oleh perusahaan yang mana pengiriman tidak sesuai dengan jadwal dalam perjanjian. Oleh karena itu UD. Bless Mebel membutuhkan supplier yang tepat.

[2] Pemilihan supplier akan menjadi kompleks ketika munculnya banyak kriteria yang menjadi pertimbangan dalam pemilihan, oleh karena suatu supplier kemungkinan mempunyai kemampuan yang baik pada beberapa. Banyak penelitian yang dilakukan dalam pemilihan supplier menggunakan pendekatan yang berbeda. [3] menggunakan metode AHP untuk memilih pemasok spare part mesin industri dengan menggunakan kriteria harga, kualitas, pelayanan, waktu pengiriman, dan responsibilitas. [4], [5] mencoba menggunakan pendekatan AHP dan DEA dalam pemilihan supplier dengan menambahkan faktor resiko.

Pemilihan Supplier pada penelitian ini menggunakan metode Fuzy Analitic Hierarchy Proces (FAHP) yang digunakan untuk menentukan keputusan dengan menggunakan banyak kriteria .

Adapun tujuan dari penelitian ini yaitu mengidentifikasi kriteria-kriteria penting untuk memilih Supplier/ pemasok kayu pada UD. Bless Mebel. Kemudian Memperoleh Supplierl pemasok terbaik yang paling memenuhi kriteria yang sudah di tentukan.

\section{BAHAN DAN METODE}

Analytic Hierarchy Process (AHP) adalah suatu metode pendukung keputusan yang dikembangkan untuk menyelesaikan permasalahan dengan memecah solusi permasalahan, mengelompokkan dan kemudian menyusunnya ke dalam suatu struktur hirarki. Untuk memperoleh kriteria yang diprioritaskan, metode ini menggunakan perbandingan kriteria berpasangan dengan skala pengukuran yang telah ditentukan. Input utama dari metode AHP adalah persepsi para pakar atau ahli, sehingga terdapat faktor subyektifitas dalam pengambilan keputusan. Metode ini juga memperhitungkan validitas data dengan adanya batas inkonsistensi [6]. Akan tetapi, ketidakpastian dan keraguan yang cukup banyak dalam memberi penilaian akan berdampak terhadap keakuratan data dan hasil yang diperoleh. Berdasarkan hal ini, dikembangkan teori lebih lanjut yaitu metode Fuzzy Analytic Hierarchy Process. Fuzzy Analytic Hierarchy Process adalah metode Analytic Hierarchy Process (AHP) yang dikembangkan dengan teori logika fuzzy, khususnya triangular fuzzy. Langkah penyelesaian masalah dengan metode Fuzzy AHP hampir sama dengan metode AHP. Hanya saja metode Fuzzy AHP mengubah skala AHP ke dalam skala triangular fuzzy untuk memperoleh prioritas. Selanjutnya, data yang telah diubah tersebut diproses lebih lanjut dengan extent analysis [7]. Pada penelitian ini penulis mencoba menerapkan metode Fuzzy AHP pada kasus pemilihan supplier pada UD. Bless Mebel dikarenakan pendekatan dengan menggunakan fuzzy khususnya triangular fuzzy number mampu meminimalisasi ketidakpastian sehingga hasil yang diperoleh lebih akurat. Penerapan metode fuzzy AHP digunakan untuk mengetahui supplier yang terbaik dengan memperhatikan kriteriakriteria yang telah ditentukan.

Terdapat tiga prinsip dasar dalam metode AHP [6], yaitu dekomposisi, perbandingan penilaian, dan sintesis prioritas. Dekomposisi adalah langkah memecah atau membagi masalah menjadi suatu struktur hirarki. Struktur tersebut terdiri dari tiga tingkat yaitu tingkat pertama (tujuan), tingkat kedua (kriteria) dan tingkat ketiga (alternatif). Selanjutnya, perbandingan penilaian dilakukan dengan membandingkan kriteria secara berpasangan dan diukur dengan skala perbandingan dari 1 sampai dengan 9. Bobot penilaian yang diperoleh kemudian disusun ke dalam matriks perbandingan berpasangan dan dilakukan proses sintesis untuk memperoleh nilai masing-masing kriteria. Nilai masing-masing kriteria didapat dengan menghitung vektor prioritas (vektor eigen) dari matriks perbandingan berpasangan. 
Misalkan terdapat sebanyak $\mathrm{n}$ kriteria $\left(\mathrm{A}_{1}\right.$, $\left.\mathrm{A}_{2, \ldots}, \mathrm{A}_{\mathrm{n}}\right)$ dengan $\left(\frac{w i}{w j}\right) \quad(\mathrm{i}=1,2, \ldots, \mathrm{n}, \mathrm{j}=1,2, \ldots, \mathrm{n})$ adalah bobot perbandingan berpasangan, maka dapat disusun matriks perbandingan berpasangan seperti Tabel 1.

Tabel 1. Matriks Perbandingan Berpasangan

\begin{tabular}{ccccc}
\hline & $\mathrm{A}_{1}$ & $\mathrm{~A}_{2}$ & $\ldots$ & $\mathrm{A}_{\mathrm{n}}$ \\
\hline $\mathrm{A}_{1}$ & $\frac{W_{1}}{W_{1}}$ & $\frac{W_{1}}{W_{2}}$ & $\ldots$ & $\frac{W_{1}}{W_{n}}$ \\
& $\frac{W_{2}}{W_{1}}$ & $\frac{W_{2}}{W_{2}}$ & $\ldots$ & $\frac{W_{2}}{\mathrm{~A}_{n}}$ \\
$\ldots$ & $\ldots$ & $\ldots$ & & $\ldots$ \\
$\mathrm{A}_{n}$ & $\frac{W_{n}}{W_{1}}$ & $\frac{W_{n}}{W_{2}}$ & $\ldots$ & $\frac{W_{n}}{W_{n}}$ \\
\hline
\end{tabular}

Selanjutnya dilakukan pengujian untuk mengetahui kekonsitenan dari penilaian. Pengujian konsistensi matriks berukuran $\mathrm{n} \times \mathrm{n}$ diperoleh dengan persamaan berikut [6]:

$$
C I=\frac{(\lambda m a k s-n)}{(n-1)}
$$

dengan,

$$
\begin{aligned}
\mathrm{CI}= & \text { Rasio penyimpangan (deviasi) } \\
& \text { konsistensi (consistency index) } \\
\text { Kmaks = } & \text { Nilai eigen terbesar dari matriks } \\
& \text { berordor } \mathrm{n} \\
\mathrm{n} \quad= & \text { Banyak kriteria }
\end{aligned}
$$

Batas ketidakkonsistenan (inconsistency) ditentukan dengan menggunakan Rasio Konsistensi (CR), yaitu perbandingan indeks konsistensi (CI) dengan nilai random index (RI) yang diperlihatkan pada Tabel 2. Nilai ini bergantung pada n. Dengan demikian, Rasio Konsistensi dirumuskan sebagai berikut [6], [8]:

$$
\begin{aligned}
C R & =\frac{C I}{R I} \\
\mathrm{CR} & =\text { Consistency Ratio } \\
\mathrm{RI} & =\text { Random Index }
\end{aligned}
$$

Tabel 2. Nilai Random Index (RI)

\begin{tabular}{c|c|c|cccccccccc}
\hline $\mathbf{n}$ & 1 & 2 & 3 & 4 & 5 & 6 & 7 & 8 & 9 & 10 & 11 \\
\hline $\mathbf{R I}^{\prime} 0,00$ & 0,00 & 0,58 & 0,9 & 1,12 & 1,24 & 1,32 & 1,41 & 1,45 & 1,49 & 1,51
\end{tabular}

Bila matriks pairwise comparison mempunyai nilai maka ketidakkonsistenan pendapat dari pengambil keputusan dapat diterima, dan apabila nilai tidak terpenuhi maka penilaian harus diulang. Saat kondisi konsisten terpenuhi maka dilanjutkan dengan pembobotan skala triangular fuzzy number [9].

Langkah-langkah metode Fuzzy AHP sebagai berikut [7]:
1. Menghitung nilai fuzzy synthetic extent

$$
S_{i}=\sum_{j=1}^{m} M_{g_{i}}^{j}=\left[\sum_{i=1}^{n} \sum_{j=1}^{m} M_{g i}^{j}\right]^{-1}
$$

Dengan

$$
\sum_{j=1}^{m} M_{g_{i}}^{J}=\left(\sum_{j=1}^{m} l_{j}, \sum_{j=1}^{m} m_{j}, \sum_{j=1}^{m} u_{j}\right)
$$

Dan $\otimes$ merupakan operator dot product. Sedangkan untuk memperoleh nilai $\left[\sum_{i=1}^{n} \sum_{j=1}^{m} M_{g_{i}}^{j}\right]^{-1} \quad$ dilakukan operasi penjumlahan untuk keselurahan bilangan triangular fuzzy $M_{g_{i}}^{j}(\mathrm{j}=1,2, \ldots, \mathrm{m})$ yaitu :

$$
\sum_{i=1}^{n} \sum_{j=1}^{m} M_{g_{i}}^{j}=\left(\sum_{i=1}^{n} \sum_{j=1}^{m} l_{i j}, \sum_{i=1}^{n} \sum_{j=1}^{m} m_{i j}, \sum_{i=1}^{n} \sum_{j=1}^{m} u_{i j}\right.
$$

Jadi

$\left[\sum_{i=1}^{n} \sum_{j=1}^{m} M_{g_{i}}^{j}\right]^{-1}$

$$
\approx \frac{1}{\sum_{i=1}^{n} \sum_{j=1}^{m} u_{i j}}, \frac{1}{\sum_{i=1}^{n} \sum_{j=1}^{m} u_{i j}}, \frac{1}{\sum_{i=1}^{n} \sum_{j=1}^{m} u_{i j}}
$$

2. Menghitung perbandingan tingkat kemungkinan antara bilangan fuzzy

Untuk dua bilangan triangular fuzzy $\mathrm{S}_{1}=$ $\left(l_{1}, \mathrm{~m}_{1}, \mathrm{u}_{1}\right)$ dan $\mathrm{S}_{1}=\left(\mathrm{l}_{2}, \mathrm{~m}_{2}, \mathrm{u}_{2}\right)$ dengan tingkat kemungkinan $\left(S_{1} \geq S_{2}\right)$ dapat didefenisikan oleh persamaan berikut :

$V\left(S_{1} \geq S_{2}\right.$

$$
\begin{array}{cl}
1 & \text {, Jika } m_{1} \geq m_{2} \\
0 & \text { Jika } l_{2} \geq u_{1} \\
\frac{l_{2}-u_{1}}{\left(m_{1}-u_{1}\right)-\left(m_{2}-l_{2}\right)}, & \text { lainnya }
\end{array}
$$

3. Menghitung tingkat kemungkinan untuk bilangan fuzzy

Tingkat kemungkinan bilangan fuzzy didefinisikan sebagai berikut:

$$
\begin{gathered}
d^{\prime}\left(A_{i}\right)=\min V\left(S_{i} \geq S_{k}\right) \\
k=1,2, \ldots, n ; k \neq i
\end{gathered}
$$

Sehingga diperoleh vector bobot

$$
W^{\prime}=\left(\left(d^{\prime}\left(A_{1}\right), d^{\prime}\left(A_{2}\right), \ldots, d^{\prime}\left(A_{n}\right)\right)^{T}\right.
$$

4. Menormalisasi vektor bobot

Vektor bobot yang masih dalam bentuk bilangan fuzzy selanjutnya dinormalisasi dengan persamaan:

$$
\begin{aligned}
& d\left(A_{i}\right)=\frac{d^{\prime}\left(A_{i}\right)}{\sum_{i=1}^{n} d \prime\left(A_{i}\right)} \\
& \text { Untuk I }=1,2, \ldots, \mathrm{n}
\end{aligned}
$$


Tabel 3. Skala AHP dan Triangular Fuzzy Number

\begin{tabular}{cccl}
\hline Skala AHP & Skala Fuzzy & Invers Skala Fuzzy & \multicolumn{1}{c}{ Keterangan } \\
\hline 1 & $(1,1,1)$ & $(1,1,1)$ & Sama Penting \\
2 & $(1,2,3)$ & $(1 / 3,1 / 2,1)$ & Skala antara sama dan sedikit lebih penting \\
3 & $(2,3,4)$ & $(1 / 4,1 / 3,1 / 2)$ & Sedikit lebih penting \\
4 & $(3,4,5)$ & $(1 / 5,1 / 4,1 / 3)$ & Skala antara sedikit lebih dan lebih penting \\
5 & $(4,5,6)$ & $(1 / 6,1 / 5,1 / 4)$ & Lebih penting \\
6 & $(5,6,7)$ & $(1 / 7,1 / 6,1 / 5)$ & Skala antara lebih dan sangat penting \\
7 & $(6,7,8)$ & $(1 / 8,1 / 7,1 / 6)$ & Sangat penting \\
8 & $(7,8,9)$ & $(1 / 9,1 / 8,1 / 7)$ & Skala antara sangat dan mutlak lebih penting \\
9 & $(8,9,9)$ & $(1 / 9,1 / 9,1 / 8)$ & Mutlak lebih penting \\
\hline
\end{tabular}

\section{HASIL DAN PEMBAHASAN}

Berdasarkan permasalahan diperoleh struktur Hirarki (Gambar 1). Selajutnya kriteria dibandingkan secara berpasangan dan diberi bobot penilaian. Pada penelitian ini, dengan menggunakan skala kepentingan yang dijelaskan oleh Saaty didefenisikan skala tingkat kepentingan dan variabel penelitian sebagai berikut :

Tabel 4. Skala Tingkat Dominan

\begin{tabular}{cc}
\hline $\begin{array}{c}\text { Tingkat } \\
\text { Kepentingan }\end{array}$ & Defenisi \\
\hline 1 & Sama Penting \\
3 & Sedikit Penting \\
5 & Cukup Penting \\
7 & Lebih Penting \\
9 & Mutlak Penting \\
$2,4,6,8$ & Nilai diantara dua pilihan yang \\
\hline
\end{tabular}

Selanjutnya berdasarkan matriks perbandingan kriteria maka dapat diperoleh bobot AHP. Adapun Langkah-langkahnya sebagai berikut :

Langkah 1. Menjumlahkan elemen dalam satu kolom (Tabel 5).

Langkah 2. Menormalisasikan matriks dengan cara membagi elemen dengan jumlahan masing-masing kolom. Hasil ditunjukan pada tabel 6

Langkah 3. Menjumlahkan elemen dalam satu baris, kemudian membaginya dengan banyak kriteria dari matrik kriteria $(n=7)$. Hasil ditunjukan pada tabel 6.

Langkah 4. Berikutnya $\lambda_{\text {maks }}$ diperoleh dari jumlah dari matriks perbandingan dikalikan dengan bobot prioritas.

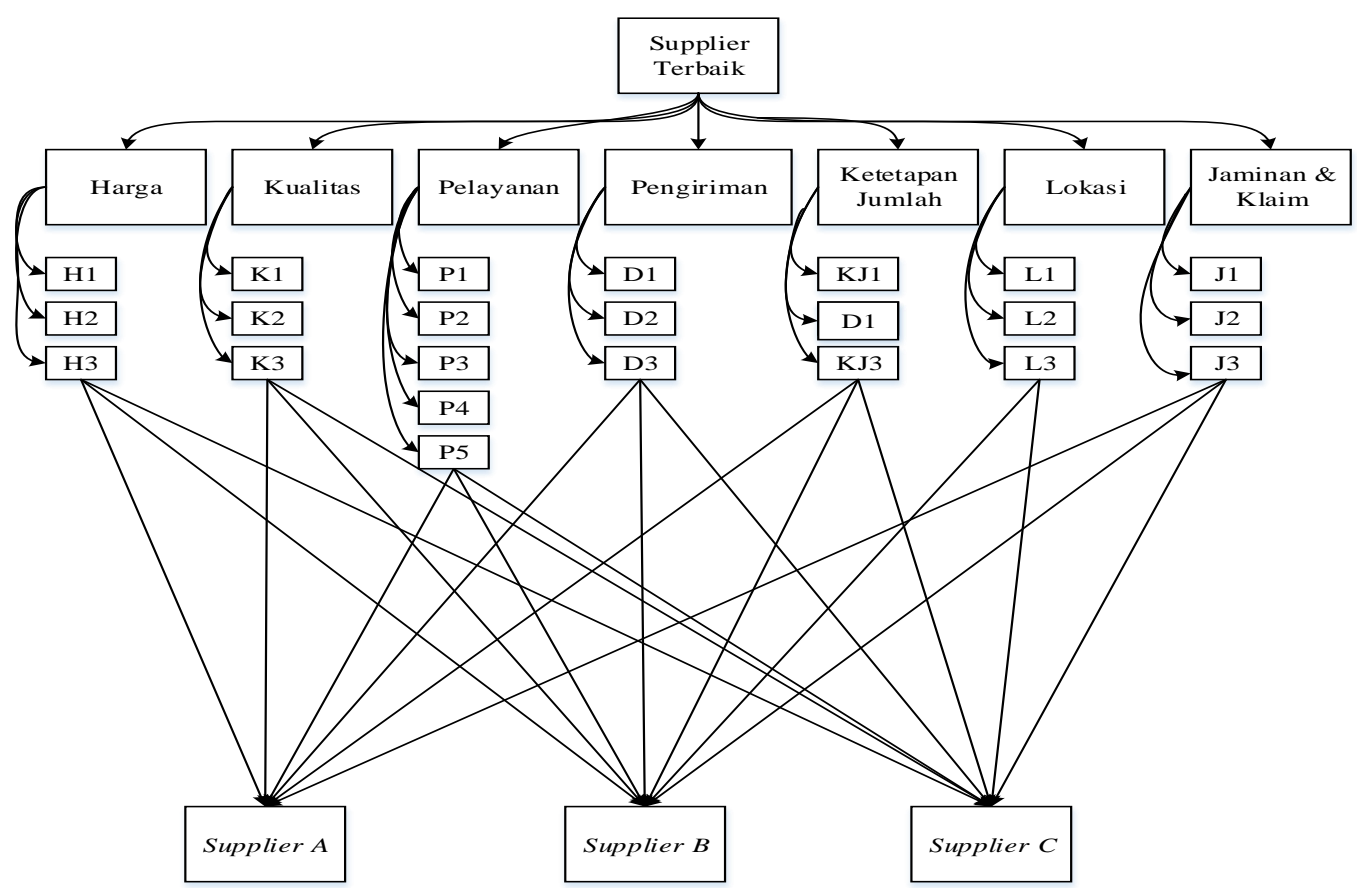

Gambar 1. Struktur Hirarki Pemilihan Supplier 
$\lambda_{\text {maks }}=(0,23 \times 4,42)+(0,25 \times 3,92)+$ $(0,12 \times 9,33)+(0,16 \times 7,33)+(0,11 \times 9)+$ $(0,06 \times 16)+(0,23 \times 15)=7,27$

Langkah 5. Berikut, dihitung nilai indeks konsistensi (CI) dengan persamaan (1) sehingga diperoleh:

$$
C I=\frac{\lambda m a k s-n}{n-1}=\frac{7,27-7}{6}=0,04
$$

Langkah 6. Berdasarkan tabel 2, untuk $\mathrm{n}=3$ maka $\mathrm{RI}=1,23$ sehingga $C R=\frac{C I}{R I}=\frac{0,04}{1,23} \quad$ (konsisten karena memenuhi syarat $\mathrm{CR}<0,1)$.

Secara keseluruhan untuk hasil perhitungan pembobotan dan uji konsistensi untuk masingmasing kriteria dan subkriteria dapat dilihat pada tabel 7 :

Tabel 5. Matriks Perbandingan Kriteria

\begin{tabular}{|c|c|c|c|c|c|c|c|}
\hline Kriteria & Harga & Kualitas & Pelayanan & Pengiriman & Ketentuan Jumlah & Lokasi & Jaminan \& Klaim \\
\hline Harga & 1 & 1 & 3 & 1 & 2 & 4 & 3 \\
\hline Kualitas & 1 & 1 & 2 & 3 & 2 & 3 & 4 \\
\hline Pelayanan & $1 / 3$ & $1 / 2$ & 1 & 1 & 1 & 3 & 1 \\
\hline Pengiriman & 1 & $1 / 3$ & 1 & 1 & 2 & 2 & 3 \\
\hline Ketentuan Jumlah & $1 / 2$ & $1 / 2$ & 1 & $1 / 2$ & 1 & 2 & 2 \\
\hline Lokasi & $1 / 4$ & $1 / 3$ & $1 / 3$ & $1 / 2$ & $1 / 2$ & 1 & 1 \\
\hline Jaminan \& Klaim & $1 / 3$ & $1 / 4$ & 1 & $1 / 3$ & $1 / 2$ & 1 & 1 \\
\hline Jumlah & 4,42 & 3,92 & 9,33 & 7,33 & 9 & 16 & 15 \\
\hline
\end{tabular}

Tabel 6. Perhitungan Bobot Prioritas AHP

\begin{tabular}{|c|c|c|c|c|c|c|c|c|c|}
\hline Kriteria & Harga & Kualitas & Pelayanan & Pengiriman & $\begin{array}{c}\text { Ketentuan } \\
\text { Jumlah }\end{array}$ & Lokasi & $\begin{array}{c}\text { Jaminan \& } \\
\text { Klaim }\end{array}$ & Bobot & Presentase \\
\hline Harga & 0,23 & 0,26 & 0,32 & 0,14 & 0,22 & 0,25 & 0,20 & 0,23 & $23 \%$ \\
\hline Kualitas & 0,23 & 0,26 & 0,21 & 0,41 & 0,22 & 0,19 & 0,27 & 0,25 & $25 \&$ \\
\hline Pelayanan & 0,08 & 0,13 & 0,11 & 0,14 & 0,11 & 0,19 & 0,07 & 0,12 & $12 \%$ \\
\hline Pengiriman & 0,23 & 0,09 & 0,11 & 0,14 & 0,22 & 0,13 & 0,20 & 0,16 & $16 \%$ \\
\hline Ketentuan Jumlah & 0,11 & 0,13 & 0,11 & 0,07 & 0,11 & 0,13 & 0,13 & 0,11 & $11 \%$ \\
\hline Lokasi & 0,06 & 0,09 & 0,04 & 0,07 & 0,06 & 0,06 & 0,07 & 0,06 & $6 \%$ \\
\hline Jaminan \& Klaim & 0,08 & 0,06 & 0,11 & 0,05 & 0,06 & 0,06 & 0,07 & 0,07 & $7 \%$ \\
\hline
\end{tabular}

Tabel 7. Bobot Kriteria dan Subkriteria

\begin{tabular}{|c|c|c|c|c|c|}
\hline Kriteria & Bobot & Prioritas & SubKriteria & Bobot & Prioritas \\
\hline & & & H1 & 0,59 & I \\
\hline \multirow[t]{3}{*}{ Harga } & 0,23 & II & $\mathrm{H} 2$ & 0,25 & II \\
\hline & & & H3 & 0,16 & III \\
\hline & & & K1 & 0,47 & I \\
\hline \multirow[t]{4}{*}{ Kualitas } & 0,26 & I & K2 & 0,38 & II \\
\hline & & & K3 & 0,15 & III \\
\hline & & & P1 & 0,35 & I \\
\hline & & & P2 & 0,08 & V \\
\hline \multirow[t]{4}{*}{ Pelayanan } & 0,12 & IV & P3 & 0,22 & II \\
\hline & & & P4 & 0,19 & III \\
\hline & & & P5 & 0,16 & IV \\
\hline & & & D1 & 0,58 & I \\
\hline \multirow[t]{3}{*}{ Pengiriman } & 0,16 & III & D2 & 0,11 & III \\
\hline & & & D3 & 0,31 & II \\
\hline & & & KJ1 & 0,37 & II \\
\hline \multirow[t]{3}{*}{ Ketetapan Jumlah } & 0,11 & V & KJ2 & 0,49 & I \\
\hline & & & KJ3 & 0,14 & III \\
\hline & & & L1 & 0,45 & I \\
\hline \multirow[t]{3}{*}{ Lokasi } & 0,06 & VII & L2 & 0,45 & II \\
\hline & & & L3 & 0,09 & III \\
\hline & & & $\mathrm{J} 1$ & 0,59 & I \\
\hline \multirow[t]{2}{*}{ Jaminan \& Kebijakan Klaim } & 0,07 & VI & $\mathrm{J} 2$ & 0,25 & II \\
\hline & & & $\mathrm{J} 3$ & 0,16 & III \\
\hline
\end{tabular}


Tabel 8. Nilai CR

\begin{tabular}{|c|c|c|}
\hline Perbandingan Berpasangan & $\mathrm{CR}$ & Keterangan \\
\hline Antar Kriteria & 0,01 & Konsisten \\
\hline Antar Kriteria Harga & 0,05 & Konsisten \\
\hline Antar Kriteria Kualitas & 0,05 & Konsisten \\
\hline Antar Kriteria Pelayanan & 0,09 & Konsisten \\
\hline Antar Kriteria Pengiriman & 0,00 & Konsisten \\
\hline $\begin{array}{l}\text { Antar Kriteria Ketetapan } \\
\text { Jumlah }\end{array}$ & 0,08 & Konsisten \\
\hline Antar Kriteria Lokasi & 0,00 & Konsisten \\
\hline $\begin{array}{l}\text { Antar Kriteria Jaminan dan } \\
\text { Klaim }\end{array}$ & 0,05 & Konsisten \\
\hline
\end{tabular}

Berdasarkan uji konsistensi diketahui bahwa perbandingan antar seluruh kriteria maupun subkriteria konsisten. Langkah berikutnya mengubah matriks perbandingan AHP kedalam skala Triangular fuszzy Number (TFN). Adapun skala TFN yang digunakan adalah skala pada tabel 3, sehingga diperoleh hasil seperti Tabel 9.

Berikutnya diilakukan proses synthetic dengan Langkah sebagai berikut :

1. Menghitung nilai fuzzy synthetic extent

Pertama akan dihitung $\sum_{j=1}^{m} M_{g_{i}}^{j}$, yaitu dengan menjumlahkan tiap-tiap bilangan fuzzy dalam setiap baris dan menghitung nilai $\left[\sum_{i=1}^{n} \sum_{j=1}^{m} M_{g_{i}}^{j}\right]$ dengan menjumlahkan keseluruhan tiap-tiap bilangan fuzzy pada baris dan kolom Sehingga diperoleh nilai $\left[\sum_{i=1}^{n} \sum_{j=1}^{m} M_{g_{i}}^{j}\right]^{-1}$ adalah $\left(\frac{1}{75}, \frac{1}{58}, \frac{1}{42}\right)$,

Menggunakan persamaan (3) dihitung nilai fuzzy synthetic extent, diperoleh :

$$
\begin{aligned}
& S K_{l}=(10 \times 14 \times 18) \times\left(\frac{1}{75}, \frac{1}{58}, \frac{1}{42}\right) \\
& =(\mathbf{0 . 1 3}, 0.24,0.43) \\
& S K_{2}=(9 \times 13 \times 17) \times\left(\frac{1}{75}, \frac{1}{58}, \frac{1}{42}\right) \\
& =(\mathbf{0 . 1 2}, 0.22,0.40) \\
& S K_{3}=(5.58 \times 6.83 \times 8.50) \times\left(\frac{1}{75}, \frac{1}{58}, \frac{1}{42}\right) \\
& =(\mathbf{0 . 0 7}, \mathbf{0 . 1 2}, 0.20) \\
& S K_{4}=(6.25 \times 9.33 \times 12.50) \times\left(\frac{1}{75}, \frac{1}{58}, \frac{1}{42}\right) \\
& =(\mathbf{0 . 0 8}, 0.16,0.30) \\
& S K_{5}=(4.67 \times 7 \times 10) \times\left(\frac{1}{75}, \frac{1}{58}, \frac{1}{42}\right) \\
& =(\mathbf{0 . 0 6}, 0.12,0.24) \\
& S K_{6}=(3.03 \times 3.42 \times 4.33) \times\left(\frac{1}{75}, \frac{1}{58}, \frac{1}{42}\right) \\
& =(\mathbf{0 . 0 4}, \mathbf{0 . 0 6}, 0.10) \\
& S K_{7}=(3.78 \times 4,08 \times 4.83) \times\left(\frac{1}{75}, \frac{1}{58}, \frac{1}{42}\right) \\
& =(0.05,0.07,0.12)
\end{aligned}
$$

\begin{tabular}{|c|c|c|c|c|c|c|c|}
\hline Kriteria & Harga & Kualitas & Pelayanan & Pengiriman & $\begin{array}{l}\text { Ketentuan } \\
\text { Jumlah }\end{array}$ & Lokasi & $\begin{array}{c}\text { Jaminan \& } \\
\text { Klaim } \\
\end{array}$ \\
\hline Harga & $(1,1,1)$ & $(1,1,1)$ & $(2,3,4)$ & $(1,1,1)$ & $(1,2,3)$ & $(3,4,5)$ & $(2,3,4)$ \\
\hline Kualitas & $(1,1,1)$ & $(1,1,1)$ & $(1,2,3)$ & $(2, ?$ & & & $(3,4,5)$ \\
\hline Pelayanan & $(1 / 4,1 / 3,1 / 2)$ & $(1 / 3,1 / 2,1)$ & $(1,1,1)$ & $(1,1,1)$ & & & $(1,1,1)$ \\
\hline Pengiriman & $(1,1,1)$ & $(1 / 4,1 / 3,1 / 2)$ & $(1,1,1)$ & $(1,1,1)$ & $(1,2,3)$ & $(1,2,3)$ & $(2,3,4)$ \\
\hline $\begin{array}{l}\text { Ketentuan } \\
\text { Jumlah }\end{array}$ & $(1 / 3,1 / 2,1)$ & $(1 / 3,1 / 2,1)$ & $(1,1,1)$ & $(1 / 3,1 / 2,1)$ & $(1,1,1)$ & $(1,2,3)$ & $(1,2,3)$ \\
\hline Lokasi & $(1 / 5,1 / 4,1 / 3)$ & $(1 / 4,1 / 3,1 / 2)$ & $(1 / 4,1 / 3,1 / 2)$ & $(1 / 3,1 / 2,1)$ & $(1 / 3,1 / 2,1)$ & $(1,1,1)$ & $(1,1,1)$ \\
\hline $\begin{array}{l}\text { Jaminan \& } \\
\text { Klaim }\end{array}$ & $(1 / 4,1 / 3,1 / 2)$ & $(1 / 5,1 / 4,1 / 3)$ & $(1,1,1)$ & $(1 / 4,1 / 3,1 / 2)$ & $(1 / 3,1 / 2,1)$ & $(1,1,1)$ & $(1,1,1)$ \\
\hline
\end{tabular}

\begin{tabular}{|c|c|c|c|c|c|c|c|c|c|c|c|c|c|c|c|c|c|c|c|c|c|c|c|c|}
\hline & \multicolumn{3}{|c|}{ Harga } & \multicolumn{3}{|c|}{ Kualitas } & \multicolumn{3}{|c|}{ Pelayanan } & \multicolumn{3}{|c|}{ Pengiriman } & \multicolumn{3}{|c|}{ etentuan Jumli } & \multicolumn{3}{|c|}{ Lokasi } & \multicolumn{3}{|c|}{ Jaminan \& Klaim } & \multicolumn{3}{|c|}{$\Sigma$} \\
\hline & $l$ & $m$ & $u$ & $l$ & $m$ & $u$ & $l$ & $m$ & $u$ & $l$ & $m$ & $u$ & $l$ & $m$ & $u$ & $l$ & $m$ & $u$ & $l$ & $m$ & $u$ & $\Sigma l$ & $\Sigma m$ & $\Sigma u$ \\
\hline Harga & 1 & 1 & 1 & 1 & 1 & 1 & 2 & 3 & 4 & 1 & 1 & 1 & 1 & 2 & 3 & 3 & 4 & 5 & 2 & 3 & 4 & 10 & 14 & 18 \\
\hline Kualitas & 1 & 1 & 1 & 1 & 1 & 1 & 1 & 2 & 3 & 2 & 3 & 4 & 1 & 2 & 3 & 2 & 3 & 4 & 3 & 4 & 5 & 9 & 13 & 17 \\
\hline Pelayanan & 0,25 & 0,33 & 0,5 & 0,33 & 0,5 & 1 & 1 & 1 & 1 & 1 & 1 & 1 & 1 & 1 & 1 & 2 & 3 & 4 & 1 & 1 & 1 & 5,58 & 6,83 & 8,5 \\
\hline Pengiriman & 1 & 1 & 1 & 0,25 & 0,33 & 0,5 & 1 & 1 & 1 & 1 & 1 & 1 & 1 & 2 & 3 & 1 & 2 & 3 & 2 & 3 & 4 & 6,25 & 9,33 & 12,5 \\
\hline Ketentuan Jumlah & 0,33 & 0,5 & 1 & 0,33 & 0,5 & 1 & 1 & 1 & 1 & 0,33 & 0,5 & 1 & 1 & 1 & 1 & 1 & 2 & 3 & 1 & 2 & 3 & 4,67 & 7 & 10 \\
\hline Lokasi & 0,2 & 0,25 & 0,33 & 0,25 & 0,33 & 0,5 & 0,25 & 0,33 & 0,5 & 0,33 & 0,5 & 1 & 0,33 & 0,5 & 1 & 1 & 1 & 1 & 1 & 1 & 1 & 3,03 & 3,42 & 4,33 \\
\hline Jaminan \& Klaim & 0,25 & 0,33 & 0,5 & 0,2 & 0,3 & 0,33 & 1 & 1 & 1 & 0,25 & 0,33 & 0,5 & 0,33 & 0,5 & 1 & 1 & 1 & 1 & 1 & 1 & 1 & 3,78 & 4,08 & 4,83 \\
\hline & & & & & & & & & & & & & & & & & & & & & & 42 & 58 & 75 \\
\hline
\end{tabular}

2. Menghitung tingkat kemungkinan fuzzy synthetic.

Dari nilai fuzzy synthetic yang telah diperoleh sebelumnya, maka dapat diperoleh perbandingan tingkat kemungkinan serta nilai fuzzy synthetic dibandingkan, selanjutnya diambil nilai minimumnya. Menggunakan persamaan (7) diperoleh

Tabel 9. Skala Perbandingan F-AHP

Tabel 10. Perhitungan Jumlah Baris Disetiap Kolom Sel 
a. $V K_{1} \geq\left(V K_{2}, V K_{3}, V K_{3}, V K_{4}, V K_{5}, V K_{6}, V K_{7}\right)$

$V\left(K_{1} \geq K_{2}\right) \geq 1$

$V\left(K_{1} \geq K_{3}\right) \geq 1$

$V\left(K_{1} \geq K_{4}\right) \geq 1$

$V\left(K_{1} \geq K_{5}\right) \geq 1$

$V\left(K_{1} \geq K_{6}\right) \geq 1$

$V\left(K_{1} \geq K_{7}\right) \geq 1$

Sehingga diperoleh nilai ordinat, $d$ '

$d^{\prime}\left(V K_{1}\right)=1$

b. $V K_{2} \geq\left(V K_{1}, V K_{3}, V K_{4}, V K_{5}, V K_{6}, V K_{7}\right)$

$V\left(K_{2} \geq K_{1}\right) \geq 0,6$

$V\left(K_{2} \geq K_{2}\right) \geq 1$

$V\left(K_{2} \geq K_{3}\right) \geq 1$

$V\left(K_{2} \geq K_{4}\right) \geq 1$

$V\left(K_{2} \geq K_{5}\right) \geq 1$

$V\left(K_{2} \geq K_{6}\right) \geq 1$

$V\left(K_{2} \geq K_{7}\right) \geq 1$

Sehingga diperoleh nilai ordinat, $d$ '

$d^{\prime}\left(V K_{2}\right)=0,6$

c. $V K_{3} \geq\left(V K_{1}, V K_{2}, V K_{4}, V K_{5}, V K_{6}, V K_{7}\right)$

$V\left(K_{3} \geq K_{1}\right) \geq 0,4$

$V\left(K_{3} \geq K_{2}\right) \geq 0,4$

$V\left(K_{3} \geq K_{4}\right) \geq 0$

$V\left(K_{3} \geq K_{5}\right) \geq 1$

$V\left(K_{3} \geq K_{6}\right) \geq 1$

$V\left(K_{3} \geq K_{7}\right) \geq 1$

Sehingga diperoleh nilai ordinat, $d$ '

$d^{\prime}\left(V K_{3}\right)=0$

d. $V K_{4} \geq\left(V K_{1}, V K_{2}, V K_{3}, V K_{5}, V K_{6}, V K_{7}\right)$

$V\left(K_{4} \geq K_{l}\right) \geq 0$

$V\left(K_{4} \geq K_{2}\right) \geq 0,7$

$V\left(K_{4} \geq K_{3}\right) \geq 1$

$V\left(K_{4} \geq K_{5}\right) \geq 1$

$V\left(K_{4} \geq K_{6}\right) \geq 1$

$V\left(K_{4} \geq K_{7}\right) \geq 1$

Sehingga diperoleh nilai ordinat, $d$ '

$d^{\prime}\left(V K_{4}\right)=0$

e. $V K_{5} \geq\left(V K_{1}, V K_{2}, V K_{3}, V K_{4}, V K_{6}, V K_{7}\right)$

$V\left(K_{5} \geq K_{1}\right) \geq 0,5$

$V\left(K_{5} \geq K_{2}\right) \geq 0,5$

$V\left(K_{5} \geq K_{3}\right) \geq 1$

$V\left(K_{5} \geq K_{4}\right) \geq 0,8$

$V\left(K_{5} \geq K_{6}\right) \geq 1$

$V\left(K_{5} \geq K_{7}\right) \geq 1$

Sehingga diperoleh nilai ordinat, $d$ '

$d^{\prime}\left(V K_{4}\right) \quad=0,5$

f. $V K_{6} \geq\left(V K_{1}, V K_{2}, V K_{3}, V K_{4}, V K_{6}, V K_{7}\right)$

$V\left(K_{6} \geq K_{l}\right) \geq 0$

$V\left(K_{6} \geq K_{2}\right) \geq 0$

$V\left(K_{6} \geq K_{3}\right) \geq 0,3$

$V\left(K_{6} \geq K_{4}\right) \geq 0,2$

$V\left(K_{6} \geq K_{5}\right) \geq 0,4$

$V\left(K_{6} \geq K_{7}\right) \geq 1,2$

Sehingga diperoleh nilai ordinat, $d$ '

$d^{\prime}\left(V K_{5}\right)=0$ g. $V K_{7} \geq\left(V K_{1}, V K_{2}, V K_{3}, V K_{4}, V K_{6}, V K_{7}\right)$

$V\left(K_{7} \geq K_{1}\right) \geq 0$

$V\left(K_{7} \geq K_{2}\right) \geq 0$

$V\left(K_{7} \geq K_{3}\right) \geq 0,5$

$V\left(K_{7} \geq K_{4}\right) \geq 0,3$

$V\left(K_{7} \geq K_{5}\right) \geq 0,5$

$V\left(K_{7} \geq K_{6}\right) \geq 1$

Sehingga diperoleh nilai ordinat, $d$,

$$
\boldsymbol{d}^{\prime}\left(V K_{5}\right)=\mathbf{0}
$$

3. Menormalisasikan vector bobot untuk matriks perbandingan kriteria dalam bilangan fuzzy

$$
\begin{gathered}
W^{\prime}=\left(d^{\prime}(K 1), d^{\prime}(K 2), d^{\prime}(K 3), d^{\prime}(K 4), d^{\prime}(K 5), d^{\prime}(K 6), d^{\prime}(K 7)\right. \\
W^{\prime} \quad=(1,0.6,0,0,0.5,0,0)^{\mathrm{T}} \\
\Sigma W^{\prime} \quad=2,11
\end{gathered}
$$

Selanjutnya vektor bobot dinormalisasi menggunakan persamaan (9), diperoleh

$$
\mathrm{W}=(\mathbf{0 . 4 7}, 0.31,0,0,0.22,0,0)
$$

Langkah dan proses yang sama dilakukan pada matriks subkritreria untuk memperoleh vektor

\begin{tabular}{|c|c|c|c|c|c|}
\hline Kriteria & Bobot & Prioritas & $\begin{array}{c}\text { Sub } \\
\text { Kriteria }\end{array}$ & Bobot & Prioritas \\
\hline \multirow{3}{*}{ Harga } & \multirow{3}{*}{0.47} & \multirow{3}{*}{ I } & H1 & 0.71 & $\mathrm{I}$ \\
\hline & & & $\mathrm{H} 2$ & 0.29 & II \\
\hline & & & $\mathrm{H} 3$ & 0 & III \\
\hline \multirow{3}{*}{ Kualitas } & \multirow{3}{*}{0.31} & \multirow{3}{*}{ II } & K1 & 0.63 & I \\
\hline & & & $\mathrm{K} 2$ & 0.34 & II \\
\hline & & & $\mathrm{K} 3$ & 0 & III \\
\hline \multirow{5}{*}{ Pelayanan } & \multirow{5}{*}{0} & \multirow{5}{*}{ IV } & $\mathrm{P} 1$ & 0.35 & I \\
\hline & & & $\mathrm{P} 2$ & 0 & $\mathrm{~V}$ \\
\hline & & & P3 & 0.27 & II \\
\hline & & & P4 & 0.21 & III \\
\hline & & & P5 & 0.18 & IV \\
\hline \multirow{3}{*}{ Pengiriman } & \multirow{3}{*}{0} & \multirow{3}{*}{ V } & D1 & 0.68 & I \\
\hline & & & D2 & 0 & III \\
\hline & & & D3 & 0.32 & II \\
\hline \multirow{3}{*}{$\begin{array}{c}\text { Ketetapan } \\
\text { Jumlah }\end{array}$} & \multirow{3}{*}{0.22} & \multirow{3}{*}{ III } & KJ1 & 0.23 & II \\
\hline & & & $\mathrm{KJ} 2$ & 0.77 & I \\
\hline & & & $\mathrm{KJ} 3$ & 0 & III \\
\hline \multirow{3}{*}{ Lokasi } & \multirow{3}{*}{0} & \multirow{3}{*}{ VI } & L1 & 0.5 & I \\
\hline & & & L2 & 0.5 & II \\
\hline & & & $\mathrm{L} 3$ & 0 & III \\
\hline \multirow{3}{*}{$\begin{array}{c}\text { Jaminan \& } \\
\text { Kebijakan } \\
\text { Klaim }\end{array}$} & \multirow{3}{*}{0} & \multirow{3}{*}{ VII } & $\mathrm{J} 1$ & 0.72 & I \\
\hline & & & $\mathrm{J} 2$ & 0.28 & II \\
\hline & & & $\mathrm{J} 3$ & 0 & III \\
\hline
\end{tabular}
bobot. Berikut bobot prioritas kriteria dan subkriteria dalam pemilihan supplier pada UD. Bless Mebel.

Tabel 11. Bobot Prioritas F-AHP

Dalam studi kasus pemilihan supplier terbaik diambil tiga supplier sebagai sampel, yaitu supplier somel ari, owner sepa, dan owner tambilow.

Tabel 12. Bobot Supplier

\begin{tabular}{ccc}
\hline Supplier & Bobot & Prioritas \\
\hline A & 0,37 & II \\
B & 0,24 & III \\
C & 0,39 & I \\
\hline
\end{tabular}


Dari tabel bobot supplier diperoleh dari bobot perbandingan subkriteria dan alternatif (supplier) dijumlahkan kemudian dibagi dengan jumlah bobot yaitu 23 maka didapatkan bobot supplier A $(0,37)$ supplier $\mathrm{B}(0,24)$ dan supplier $\mathrm{C}(0,39)$.

Berdasarkan hasil penelitian maka yang akan di prioritaskan atau dipilih sebagai supplier terbaik oleh perusahaan adalah supplier $\mathrm{C}$ maka diharapkan supplier terpilih kedepannya akan menjaga konsistensi dalam menyuplai bahan baku kepada perusahaan.

\section{KESIMPULAN}

Pada penelitian ini dapat disimpulkan bahwa dengan menerapkan metode Fuzzy Analytic Hierarchy Process diperoleh hasil bahwa:

1. Hasil pengolahan data yang dilakukan dengan metode fuzzy AHP dapat diperoleh tujuh kriteria dengan tingkat kepentingan secara berurutan yaitu kriteria harga yang menjadi prioritas pertama dalam pemilihan supplier pada UD. Bless Mebel dengan bobot $(0,47)$, kemudian kriteria kualitas dengan bobot $(0,31)$, selanjutnya kriteria ketetapan jumlah $(0,22)$ dan seterusnya untuk pelayanan, pengiriman, lokasi, jaminan dan kebijakan klaim memiliki bobot 0 .

2. Dengan memperhatikan ketujuh kriteria diatas maka diperoleh supplier yang direkomendasikan untuk diprioritaskan adalah supplier terbaik berdasasrkan bobot prioritas tertinggi yaitu supplier C (Supplier Sepa) dengan bobot $(0,39)$ kemudian supplier A (Somel Ari) $(0,37)$ dan yang ketiga adalah supplier B (Supplier Tambilow) $(0,24)$.

Penelitian yang dilakukan ini berhubungan dengan keperluan UD. Bless Mebel saat ini, sehingga waktu, kondisi dan tempat yang berbeda perlu dilakukan penelitian lanjutan. Potensi riset mendatang yang dapat dikembangkan dari penelitian ini adalah dengan menggunakan metode lain yang lebih kuantitatif seperti dikombinasikan dengan metode Data Envelopment Analysis (DEA).

\section{DAFTAR PUSTAKA}

[1] Ernawati, D., Suryadi, A. and Erlina (2017) 'Analisis Pemilihan Supplier Terbaik Untuk Bahan Baku Utama Menggunakan Metode ( Studi Kasus : Pt . Kedaung Indah Can Tbk .)', Tekmapro: Journal of Industrial Engineering and Management, 12(02), pp. 1-12.

[2] Darmawan, H. and Setiawan, H. (2013) 'Pemilihan Pemasok Bahan Baku Produksi Menggunakan Metode Data Envelopment Analysis', Jurnal Teknik Industri, 1(2), pp. 157-161.

[3] Wulandari, N. (2014) 'Perancangan Sistem Pendukung Keputusan Pemilihan Supplier di PT . Alfindo dengan Metode Analytical Hierarchy Process (AHP)', Jurnal Sistem Informasi Vol-1, 1(1), pp. 4-7.

[4] Lim,J. J., and Zhang, A.N. (2016). A DEA approach for Supplier Selection with AHP and risk consideration., 2016 IEEE International Conference on Big Data. pp. 3749-3758.

[5] Latuny, W., Paillin, D. B. and Yaniah, S. (2020) 'Kombinasi Analytical Hierarchy Process (AHP) dan Data Envelopment Analysis (DEA) untuk Pemilihan Supplier Pada UD. Jepara Putra Mebel', Performa: Media Ilmiah Teknik Industri, 19(2), pp. 141150. doi: 10.20961/performa.19.2.46324.

[6] Saaty, T. L. \& Kearns, K. P., 1985. Analytical Planning The Organization of Systems. Pergamon Press

[7] Chang, Da-Yong, 1996. Applications of the Extent Analysis Method on Fuzzy AHP. European Journal Of Operational Research, pp. 649-655.

[8] Saaty, T. L. \& Vargas, L. G., 2001. Models, Methods, Concepts \& Applications of the Analytic Hierarchy Process. New York: Springer Science + Business Media

[9] Hsu, Yu-Lung, Lee, Cheng-Haw. \& V.B. Kreng, 2010. The application of Fuzzy Delphi Method and Fuzzy AHP in lubricant regenerative technologi selection. Expert System with Application, pp. 419-425 